\title{
Comparative Study of Auto Plan and Manual Plan for Nasopharyngeal Carcinoma Intensity-Modulated Radiation Therapy [Corrigendum]
}

\author{
Xin X, Cheng C, Li C, et al. Cancer Manag Res. \\ 2020;12:12439-12445. \\ The authors have advised that the funding statement \\ was not included in their submitted manuscript and \\ therefore, was not included on page 12444 of the \\ published paper. The funding statement should read as \\ follows:
}

\section{Funding}

Sichuan provincial commission of health and family planning project (16PJ512), Sichuan medical association project (S17068), Sichuan provincial science and technology department special plan (2017SZ0004), Sichuan provincial science and technology department project (2019YFG0185).

The authors apologize for this error.

\section{Publish your work in this journal}

Cancer Management and Research is an international, peer-reviewed open access journal focusing on cancer research and the optimal use of preventative and integrated treatment interventions to achieve improve outcomes, enhanced survival and quality of life for the cancer patient.
The manuscript management system is completely online and includes a very quick and fair peer-review system, which is all easy to use. Visit http://www.dovepress.com/testimonials.php to read real quotes from published authors. 